\title{
A Qualitative case study on inadequate public transport system and its social impact on people in Dhaka
}

\author{
SAHED HOSSEN SAJIB \\ Department of Rural Sociology, Bangladesh Agricultural University, Mymensingh, 2202, Bangladesh \\ Department of Sociology, University of Barishal, Kornokathi, (Dhaka-Patuakhali Highway), Barishal, 8254, Bangladesh
}

KEYWORDS: Case Study, Public Transport, Qualitative Content Analysis, Social Impact Assessment, Urban Transport.

ABSTRACT: This case study research assesses the social impacts of inadequate transport facilities on the people of the city of Dhaka using the qualitative content analysis method. From livelihood to the urban communities mobility, all life-related matters are directly or indirectly related to public transport. However, the transport system in this city is one of the worst in the world. Hence, there is an absolute necessity to examine the inadequate transport facilities of the present transit system and their social effects on the people living in this city. Vanclay's Social Impact Assessment was integrated to investigate the impact. In six specific gateways of Dhaka, indepth interviews with 1800 respondents were carried out to know about the social impacts of insufficient public transport facilities. The social impacts of inadequate transport facilities create problematic conditions specifically for the low and middle-income communities of Dhaka, aggravating traffic danger, absence of protection and safety, social isolation, reduced mobilities, loss of social capital, cultural deprivation, absence of social interaction, family estrangement, travel cost, deficiency of transport accessibility. In the future, it will have serious repercussions for its residents.

\subsection{INTRODUCTION:}

Dhaka, the capital city of Bangladesh, is one of the most densely populated cities globally. Its contribution to the GDP of the country is near about $40 \%$. About $9 \%$ of the country's total population lives in this city (Ahmed and Ahmed, 2017). This urban sprawl contains about 20 million inhabitants (UN, DESA, 2018, p. 76). The high birth rate is not the chief reason behind its population growth. The substantial influx of settlers from other cities and villages pave the way to the high compactness of the population for this city (INTALInC, 2019, p. 12). The number of government registered motor vehicles in this city was more than two million in 2019 (BBS., 2019, p. 235). However, they are not well organised and maintained by the authorities of this city. The absence of an exact schedule and fixed vehicle stoppage are typical transport service scenarios in Dhaka (Zahir, Matsui, and Fujita, 2000). Dhaka's public transport condition can be well-defined by traffic suspensions, discomfort, limited traffic supervision, overcrowd, high accident rates, and air pollution problems (Mustaqeem, Jalaluddin, and Hassan, 2016). These poor conditions of the transport sector directly or indirectly affect people's social lives, limiting accessibility and exacerbating the deprivation of essential resources like education, health facilities, employment, and other social services (Miller, 2004). Dhaka City's transit classification is primarily road-based, though it has a confined rail and watercourses route. Still, this city has no mass transit system like metro rail or bus rapid transit. Like other South Asian cities, non-motorised transport and public transport predominately serve here (Munsi, 2015). The majority of people in this city have to use public transport as the only means of travel (JICA and DTCA, 2015; Olsson and Thynell, 2006). Public transport is a passenger transport that works in exchange for a reward or hires with the general public (Fitzgerald, 2012, p. 16). In addition to its users' comfort, public transportation acts as an active part of cities' production (Rahman, Das, and Hadiuzzaman, 2016).
Thus, it has straight comportment on the national economy (Lyndon and Todd, 2006). Public transport can cause social exclusion by delivering obstruction to accessibility (Mackett and Thoreau, 2015). Accessibility refers to people's ability to get at services and activities essential for their well-being (Mitchell and Town, 1977). Social exclusion undermines or destroys channels of access to support and opportunity. It is a process that hinders individuals, families, groups, and neighbourhoods from gaining resources necessary for social, economic, and political activities that society relish (Pierson, 2010, p. 23). In this study, the researcher observed how an inadequate transport system affects the city community. The researcher seeks to integrate Vanclay's Social Impact Assessment (SIA) to assess the social impact of inadequate transport facilities on people. Social impact assessment is an intrinsic component of Environmental Impact Assessment (EIA). It emerged as a separate field of applied social science because Environmental Impact Assessment (EIA) could not sufficiently address social issues (Momtaz, 2005). Social Impact Assessment (SIA) comprises the procedures of analysing, monitoring, and managing the intended and unintended social consequences, both positive and negative, of planned interventions (policies, programs, plans, projects) and any social change processes invoked by those interventions (Vanclay, 2003). The suitable way of abstracting the impacts with Vanclay SIA was finding:

1. Impact on Health and Wellbeing.

2. Impact on Culture.

3. Impact on Legal, Personal, Political, Property rights, and Equity.

4. Impact on Community, social networks, and Institutions.

5. Impact on Peoples' way of living, environment, convenience.

6. Material Well-being.

7. Impact on Fears and Aspiration

(Van Schooten et al., 2003, p. 75). 
SIA was constructed with the findings from the case study interview. The case study was the most widely used method for Social Impact Assessment (Jain, Urban, Balbach, and Webb, 2012, p. 281). SIA assesses all positive and negative impacts on humans and how they interact with their socio-cultural, economic, and biophysical surroundings. All these impacts are inherently interconnected. Change in one domain alters another domain (Vanclay, 2003), and impacts must be experienced or felt (Van Schooten et al., 2003, p.84). The qualitative data collection gathers the experiences, thoughts, and feelings of the participants (Moser and Korstjens, 2018). Therefore, qualitative data was appropriate for this study.

\subsection{RESEARCH QUESTIONS:}

1. What are the significant social impacts of low transport quality on people in Dhaka city?

2. What are the consequences of the impact of inadequate and low transport facilities on urban communities in Dhaka city?

\subsection{LITERATURE REVIEW:}

Not many studies have been done on the social impact of inadequate transit service in the city of Dhaka. The researcher tried to review the literature related to the social impacts of inadequate transport facilities.

Literature Review Related to Dhaka's Transport System: Quddus et al. (2019) disclosed that the inhabitants of Dhaka are not satisfied with the present public transport facilities. It is unreliable, unsafe, inefficient. It also results in reduced mobility for the passengers. Andaleeb, Haq, and Ahmed (2007) tried to explore the way of improving bus transit service in Dhaka. Their statistical model found that the waiting facilities, traffic management, and traffic staff behaviour affect passenger gratification.

Public transport in Dhaka cannot guarantee protected, comfortable, and safe travel for disabled groups and women (Abir and Hoque, 2011; Rahman, 2010). Rahman and Nahrin (2012) argued that public transport in Dhaka is frequently unavailable for women, the elderly, and the disabled. According to Mazumder and Pokharel (2018), in the urban areas of Bangladesh, sexual harassment against women on public transportation creates an unfavourable environment for their empowerment. However, this problem has remained remarkably inconspicuous in society due to under-reporting. Thus, this problem has not gained national acknowledgement. Mannan and Ahmed (2014) illustrated that misbehaviour, unwanted attitude by male passenger towards women in overcrowded buses impede women's mobility. Ahmed, Alam, and Warda (2017) tried to gain new insight into the sustainable urban transport system by introducing the rapid transit system. They showed that Bus Rapid Transit (BRT) would help Dhaka gain the Sustainable Development Goal (SDG) number 11,13 , and 3. Nasrin, Bunker, and Zheng (2015) projected that specifically male and older workers and workers with higher income and educational qualification would have a higher tendency to choose Bus Rapid Transit (BRT) in this city. According to Kartz and Rahman (2010), inadequate transport substructure, overcrowded buses, and inappropriate traffic control are widespread in Dhaka. They create unsafe situations, which detract from the transport system's performance and comfort of the commuters. Mahmud, Gope, and Chowdhury (2012) showed that traffic congestion wastes a considerable share of working hours by forcing us to stay on the roads for an extended period of time, which obliquely harms the economy. According to them, wrong traffic signal systems, insufficient workforces, narrow road spaces, and overtaking tendencies create prolonged traffic congestion. Barua and Tay (2010) considered security topics of transportation services in Dhaka. According to them, strict traffic rules, training programs, robust traffic control, and instructive programs can reduce road accidents and other transport system obstacles. Mahmood (2011) indicated that lack of public consciousness, old vehicles, and bad quality fuel are responsible for high air and noise pollution in this city. However, research related to transports in the context of the social impact of Dhaka is minimal. There is no research available providing deep insight into social issues related to the transport system in Dhaka.

\section{Social Impacts of Inadequate Transport System:}

Travel satisfaction is associated with commuters' well-being and life satisfaction (Smith, 2013; Bergstad et al., 2011; Ettema et al., 2010; Friman et al., 2017; McCarthy and Habib, 2018). Khan et al. (2018) stated that traffic congestion causes social problems and affects urban dwellers' social and economic conditions. Kay (2011) explained that challenges and harm caused by transport problems mainly affect the disadvantaged people in a transport-dependent society. Mindell et al. (2017) showed that impoverished people in urban areas are more likely to live in an area full of traffic. High traffic speed, traffic interference, high volume of significant traffic infrastructure in those areas result in noise pollution, higher injury and fatality rates, and community severance. Schalkwyk and Mindell (2018) added that a poor transport system causes more community severance, air pollution, noise pollution, road traffic fatality. It is also the cause of poor mental health, reduced interconnection, lack of social interaction. According to Mackett (2014), the health impact of transport is dispersed unequally among populations. Foley et al. (2017) endorsed the notion that living adjacent to a motorway deteriorates residents' well-being, particularly people with chronic illness. Mackett \& Thoreau (2015) described that transport-related adverse health effects are hearing damage caused by unnecessary noise, lung diseases caused by discharged pollutants, community severance, which leads to break the harmony of communities and additional lousy health conditions. Mindell et al. (2014) contended that lack of transport accessibility increases physical inactivity and sedentary behaviour, which can raise health risk, isolation problem, mental stress, anxiety, cardiovascular diseases, community severance, loneliness, lung cancer, respiratory diseases, obesity, infectious disease like influenza, and gastrointestinal diseases and so on. Mullan (2003), Bosselmann, Macdonald, and Kronemeyer (1999) investigated that the high traffic level and speed can lower interactions among communities on both sides of the road. Stanley et al. (2010) argued that travel appears to be exceedingly dominant on social networking, encouraging a sense of belonging and active participation in the community or society. Metz (2000) described that access to people and places could provide a range of physiological and psychological benefits. Metz (2000) further added that people who have difficulty accessing transport have infrequent 'bridging' contacts and interactions. Bostock (2001) examined that not owning a car can also negatively impact a family's well-being, especially with low income-lonely mothers and their children. Smith and Egger (1992) believed that living standards decline when people do not own a car.

While travelling in transport, women are negatively affected by safety and security threats (Gekoski et al., 2015; Loukaitou-Sideris 2016; Peters 2013). They are vulnerable to exposure and sexual harassment on public transit nearly every day around the world (Gekoski et al., 2017). Gardner, Cui, and Coiacetto (2017) found that most women are afraid of travelling alone and travelling at night, limiting their access to public spaces. Church, Frost, and Sullivan 
(2000); Lucas (2012) revealed that fear of personal protection could lead to the social exclusion of women and other social classes by prohibiting them from accessing public spaces or transportation facilities.

This condition is especially true for low-income, minority women who live in high-crime neighbourhoods with limited transit choices (Loukaitou-Sideris, 2014, p. 243). Unlike men, women prefer to use public transportation only at certain hours of the day or with their families or relatives (Atkins, 1989; Ross, 2000). According to Dunckel-Graglia (2013), one of the most significant impediments to women's mobility is their fear of being victimised in public places and public transport. It has been proposed that such anxiety is a consequence of gender inequality in the transit system. LoukaitouSideris (2009) claimed that, for women, riding buses is better than waiting at a bus stop because a bus driver's presence is more comforting than the unpredictability situation of bus stops.

The literature review has recognised that poor and low traffic conditions have unpleasant effects on customers and commuters. However, no study has assessed the social impact of the inadequate transport system with qualitative analysis in Dhaka. This research provides a noteworthy investigation of social impact on the residents of Dhaka using qualitative content analysis.

\subsection{METHODOLOGY:}

\section{Research Types:}

It was an explorative qualitative research approach. Qualitative content analysis was applied to find out the social impact of inadequate transport facilities. The in-depth unstructured interviews were considered to gather information from the transport user about travel modes, travel purposes, transport accessibility, conveniences, well-being, service condition, way of living, communities, and institutions' patterns.

\section{Sampling Technique and Informants:}

The sampling in qualitative research is described as purposive. The importance is given to the research participants to gain insight into the illuminative and rich information sources (Patton, 2002, p. 40). In this study, the purposive non-probability sampling design was selected. In purposive sampling, the selection process is directed by the qualities of potential participants (Farrugia, 2019, p. 70), and the researcher initially interviews those who have undergone the typical experiences with the topics (Coyne, 1997, p. 628). As we selected informants as a sample, who have to use transport every day, this sampling technique was appropriate for this study. A total of eighteen hundred $\mathbf{n}=\mathbf{1 8 0 0}$ respondents participated in the interview. Among six locations, each location had a size of three hundred participants for the interview. Three hundred respondents were not needed in every study location. In many study locations, saturation was achieved before conducting 300 interviews. Saturation in qualitative research is a point in coding when researchers find that no new code occurs in the data (Urquhart, 2013, p. 194), and there is a little need for more sampling (Suter, 2012, p. 350). Besides, new information would cause the replication of already collected data (Grady, 1998, p. 26; Guest, Bunce, and Johnson, 2006). However, the researcher kept this considerable sample size to maintain all social groups and urban communities' equal participation. In Social Impact Assessment (SIA), an equally effective public participation strategy should be maintained (Lockie, 2001, p. 278). In this study, all respondents were the Dhaka division inhabitants, irrespective of their income, social status, gender, and educational background. Participants from the interview were more than 18 years old.

\begin{tabular}{|c|c|c|c|}
\hline Variables & Criterion & Frequency & Percentage \\
\hline \multirow[t]{3}{*}{ Gender } & Male & 900 & $50.00 \%$ \\
\hline & Female & 812 & $45.11 \%$ \\
\hline & Others, LGBT & 88 & $4.89 \%$ \\
\hline Age & More than 18 & & \\
\hline \multirow{3}{*}{$\begin{array}{l}\text { Educational } \\
\text { status }\end{array}$} & Illiterate & 219 & $12.17 \%$ \\
\hline & Below bachelor's degree & 557 & $30.94 \%$ \\
\hline & Bachelor or Higher & 1024 & $56.89 \%$ \\
\hline \multirow{10}{*}{$\begin{array}{l}\text { Participants } \\
\text { occupation }\end{array}$} & Teachers & 69 & $3.83 \%$ \\
\hline & Professional drivers & 324 & $18.00 \%$ \\
\hline & Police & 93 & $5.17 \%$ \\
\hline & Students & 223 & $12.39 \%$ \\
\hline & Street Vendor or Hawkers & 111 & $6.17 \%$ \\
\hline & Priest & 13 & $0.72 \%$ \\
\hline & Doctors & 126 & $7.00 \%$ \\
\hline & Engineers & 356 & $19.78 \%$ \\
\hline & Government Employees & 277 & $15.39 \%$ \\
\hline & Businessman & 208 & $11.56 \%$ \\
\hline
\end{tabular}

Note. Information on participants.

Table 1. Social Profiling (Baseline Data).

\section{Data Collection Instrument:}

All respondents in the study were interviewed through the unstructured questionnaire with the presence of the researcher. It was precisely a non-directive interview in which respondents were free to speak about anything related to the topics (Gray, 2014). At the beginning of every interview, a brief introduction of the study was given to the participants. Before the interview, every questionnaire was piloted. Pilot testing helps researchers detect unanticipated data collection problems (Rubin and Babbie, 2011, p. 287). In this study, it helped whether the types of questions or wording need refining or not. The actual interview was done entirely in Bengali. Then the researcher translated all the information into English without altering the original context and meaning. Each interview was taped and lasted 30 to 45 minutes. Interview questions were open-ended and specific to the participants' comments (Hsieh \& Shannon, 2005, p. 1279) because the conventional content analysis was used for the data analysis method.

Study Setting and Locations of the Study:

\begin{tabular}{llc}
\hline $\begin{array}{l}\text { Serial of } \\
\text { the Locations }\end{array}$ & Name of the Locations & $\begin{array}{c}\text { Sample } \\
\text { size }\end{array}$ \\
\hline L.1 & Sayedabad Bus Terminal & 300 \\
L.2 & Mohakhali Bus Terminal & 300 \\
L.3 & Mawa Shimulia Louhajang & 300 \\
& Launchghat Bus Terminal & \\
L.4 & Sadarghat Launch Terminal Bus Stop & 300 \\
L.5 & Gabtoli Bus Terminal & 300 \\
L.6 & Gazipur Chowrasta Bus Stand & 300 \\
\hline
\end{tabular}

Note. Six Locations of the interview.

Table 2. Selected Locations where interviews were conducted.

Interviews were conducted at six locations of the Dhaka division. Among six, the five locations are parts of the Greater Dhaka Area (GDA). They were Sayedabad bus terminal, Mohakhali bus terminal, Gabtoli bus terminal, Sadarghat Launch Terminal bus stop, and Gazipur Chowrasta bus stand. Another location, Mawa Shimulia Louhajang Launchghat bus termi- 
nal, is in the Dhaka division, but not in the Greater Dhaka Area (GDA). The selected locations remain busy all the time with transportations and commuters.

Location and the Route of the Study from Google Map:

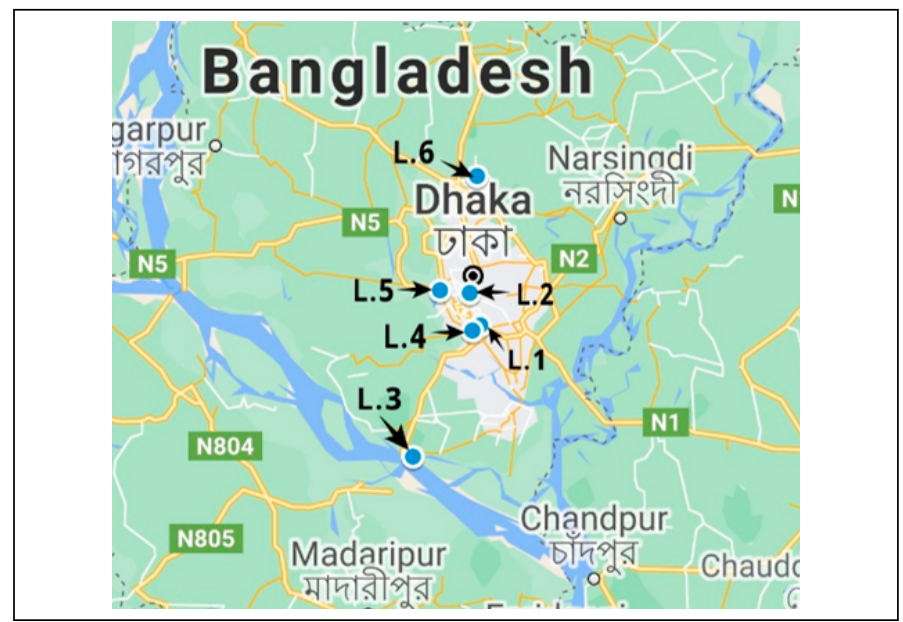

Figure 1. Locations of the Study.

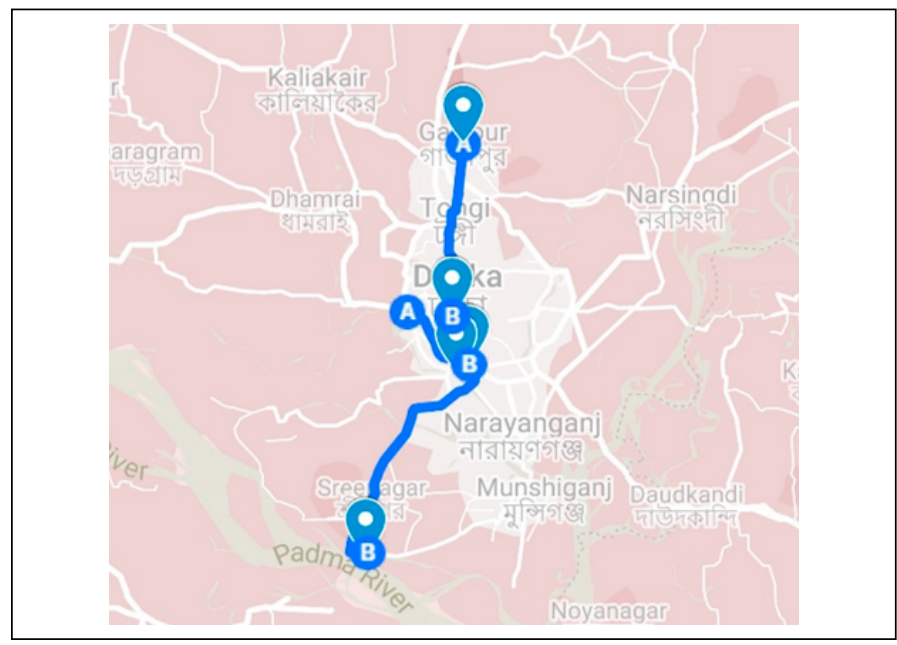

Figure 2. Route of the Study Area in Blue Line

\section{Research Design and Data Analysis Procedure:}

The researcher tried to gain insight into the subjective meaning of the transport-related complex phenomenon of urban communities (Rubin and Babbie, 2011, p. 67). To understand the complex phenomenon, we must contemplate the multiple reality "insider perspective" experienced by participants in qualitative inquiry (Suter, 2012, p. 344). So, the researcher chose the qualitative method. The data analysis procedure used in this study was qualitative content analysis. Qualitative content analysis has three distinct approaches: conventional, directed, and summative. The conventional approach pursues themes and their labels directly from text data (Hsieh and Shannon, 2005). It starts with the relevant research findings (Patton, 2002), highlighting the exact word from the text (Hsieh and Shannon, 2005). This conventional qualitative content analysis design is suitable when the existing theory or research literature on a phenomenon is limited, and researchers use categories from the flow of data (Kondracki, Wellman, and Amundson, 2002). Therefore, with limited knowledge about the social impact of the transport system in Dhaka, the conventional approach was used in this study. To code the interview findings, the researcher broke down the text or documents into a single unit of analysis - "meaning units" (Krippendorff, 1980; Bengtsson, 2016). According to the coding list, the researcher labelled every meaning unit with a code (Berg, 2001). Codes such as loss of social interaction, family estrangement, disruption of the socialisation process, losses of social capital, and community severance seemed to express the impact on the family, community, and social networks. Likewise, other codes and themes were developed to explain the subjective and underlying phenomenon of the study. When obtainable, the additional information and secondary data were encompassed in this qualitative content analysis. All the effects and social consequences were demonstrated through Vanclay's Social Impact Assessment (SIA). The researcher chose SIA to reveal the social impact of the poor transit system because it examines the impact of culture, quality of life, health and well-being, community, institutions, political structures, and people's economic conditions. Social impact in SIA is comprehensive and includes many aspects of human life at various levels of social aggregation from family to society as a whole (Van Schooten et al., 2003, p. 84). I expect Vanclay's SIA will outweigh the other techniques of impact assessment in this transport-based study.

\subsection{RESULT AND DISCUSSION:}

Social Impact Assessment (SIA) based on Case Interview: The following sections outline the core social impacts of inadequate transport facilities on Dhaka City people using Vanclay's social impact assessment. All the pieces of information below were analysed with qualitative content analysis. The findings are represented below:

\section{Health Impacts:}

Low or limited access to transport increases the probability of loneliness and depression that later prompts social isolation. Misery resulting from isolation lowers people's ability to work and connect with others. This condition is prevalent among Dhaka's residents. The insufficient access to cultural, artistic, recreational activities and meeting places due to poor transport also contributes to depression, ill-health and mental illness among communities. Health risks arising from isolation or other causes may arise due to inadequate access to healthcare services, especially for people who live far away from the hospitals. Without access to transport, respondents do not have easy access to medical assistance when they are ill and subsequently face more difficulty than they might otherwise have. This situation increases the risk of severe illness or death because people cannot get urgent medical help quickly. It is relevant in remote and impoverished areas, specifically severe in location no.3, where local doctors and medical services are not available. Remoteness from services is a significant source of anxiety for many respondents with the worst medical conditions. This remoteness leads people to relocate closer to medical services. Later this relocation causes family estrangement. Moreover, severe traffic jams prevent ambulances or other patient-carrying vehicles from arriving on time at the hospital. In some cases, inadequate transport access in Dhaka has some health benefits too. Those with little access to transport have to walk a lot. Walking a lot can contribute to their physical and mental well-being (Field interview, 2020). Major meaning units associated with this case are mentioned below:

"I was unable to get medical assistance as my home was very far away from the central hospital. [Teacher, Female].

The local and nearby medicals are not capable of providing all medical solutions. [Businessman, Male].

I was not able to reach the hospital on time during my father's emergency. Later, the probability of future undesired event gave more stress on me. [Student, Male].

I could not connect with my friends and my fellow workers from the remote area. I feel lonely and depressed during weekends. [Student, Female] 
I have to live in a house in the centre of the capital, far away from my family, where medical services and other facilities are available. In our local area, these facilities are not convenient and inaccessible. [Student, Female]" (personal communication, January 2020).

Impact on People's way of Living, Environment, Convenience:

Pedestrians are at amplified risk of road crashes and injuries as there is a lack of footpaths/pavement, off-road tracks, and cycleways in all study locations. In the most remote areas like location no. 3 and 6 , the lack of registered local mini public transport services led to an increase in unauthorised, unregistered, and inferior vehicles on local roads causing significant problems for registered vehicle operators by taking up road space and robbing them of their passengers. The registered vehicle operators also get frustrated since they have to pay the government for licenses and other services but do not earn enough revenues. In many places, vehicles like auto-rickshaws (three-wheeler battery-powered vehicles) dominate the roads. These transports are not approved by the transport authority and have no safety measures like a rearview mirror and hard break. They increase risks for other vehicle operators and road users by playing along with the big bus on the same roads. These types of vehicles are responsible for most of the accidents on highways. Dhaka seizes the highest number of road crashes-record 321 in 2019 among Bangladesh's other cities (BBS., 2019, p. 237).

Female passengers are mistreated everywhere on the road, as most men are misogynists due to the country's culture. There are not enough public toilets for them at bus stops or on the road. Besides, reserved seats for women, the elderly, and the disabled on public buses are often occupied by inconsiderate men. In the rainy season, the muddy, slushier pavements become death traps for the commuters. If anyone is in trouble and needs to hitchhike, nobody comes forward as hitchhiking is not widespread in this country. Most of the time, passengers have to travel standing on the bus without a seat. It detracts from the well-being and the convenience of the passengers in this city. The prevalence of old and inefficient vehicles in the city also causes air pollution. Moreover, there are no proper facilities to clean up the particulate matter, waste, and dust on the roads. Municipal and urban waste is placed in an unorganised way at the roadside in every study area. They pollute the environment and block a large portion of the roads. The unbearable noise and horn from the vehicle are widespread in every location of the interview. Most drivers do not pay any attention, whether they are near a school or hospital. From the study of Haq et al. (2012), Dhaka city exceeded the noise limit at 37 locations. This illegal sound practice by drivers causes a vulnerable situation for all commuters in this city. The illegal hawker and informal vendors block a large portion of pavements and roadsides in study location no.1, 4, and 5. This blockade by the informal sector on the road obstructs the normal flow of the transit fleet. The obstructions of transit flow cause severe traffic jams and decrease the mobility of urban residents. In every location of the study, there is no separate road for the non-motorised vehicle. Using a similar road space for both motor and nonmotor transport can weaken the current traffic system (Niger, 2013). All flyovers in Dhaka have no facilities for nonmotorised vehicles. However, the number of non-motorised vehicles is more than any other vehicle in this city. This kind of deprivation is undesirable for the non-motorised vehicledependent people in this city (Field interview, 2020). Some major meaning units are:

"Transport owners of this city always care for the capital and economic benefit. [Student, Male].
We have no facilities for the footpath, off-road tracks, and cycleways in our area. [Professional driver, Male].

In our area, the local minibuses are not available. The unregistered non-motorised transport takes the places of local minibuses on the road. [Government Employee, Female].

All the roads in our area share the same line for all kinds of transport. That disrupts the continuing transport fleet of this busy city. [Engineer, Male].

Sharing the same lane on the road for non-motorised and motorised transport is liable for the accident. [Professional driver, Male].

In most of the bus stoppage, there are no public toilet facilities. [Government Employee, Female].

In buses, social seclusion is not abode by all. Reserved seats for the disabled and female are not kept specific for them. [Professional driver, Male].

Municipal and urban waste is not clean properly by authority. So, these wastes are kept side of the road, creates a foul smell and polluted environment for passengers and commuters. [Professional driver, Male].

All the roadsides and pavement are muddy, slushier, and unusable in the rainy season. [Government Employee, Female].

Drivers and bus contractors are unfriendly with passengers. They avoid hitchhiking from passengers. [Priest, Male].

All the vehicles are not totally environment friendly. They are contributing to air and sound pollution in the city. There is no law to abate unwanted horns from vehicles. [Engineer, Male].

An expert engineer from the Bangladesh University of Engineering and Technology (BUET) assured us that all flyovers in this city have no non-motor vehicle facilities. [Engineer, Male]" (personal communication, January 2020).

\section{Impact on Culture:}

The transit system of Dhaka has a significant impact on the culture of its communities. From other parts of the country, newcomers have brought cultural diversity to this city. In many cases, individuals who have no access to alternate transport cannot easily access urban cultural centres. Consequently, they experienced cultural deprivation. A case from location no.3, most students have to go to their schools by long route buses using highway roads. However, they do not stop according to the student's requirements as students pay half fare, and according to the bus drivers, that is not enough for them. As a result, many times, students are missing their classes. Some students and other commuters perform in cultural institutions that are also disrupted by inadequate transit accessibility. In many traditional, national, and religious ceremonies, people cannot participate due to the lack of transport. For location no.3 and 6, it is tough for them to join the leading cinema theatre Bashundhara Star Cineplex or Blockbuster Cinema for the high rent of public transport. Besides, recreation and entertainment centres are situated in the centre of the capital, and due to poor transport facilities, it is difficult for people to come to the centre. They also miss many day-night international sports and games at the national stadium of Dhaka city, as after 10 p.m., all local bus services stop for the day. Thus, they are deprived of the cultural functions of the city. Poor transportation access also tended to the shortage of access to the internet, communications, and media in location no.3. They have no nearby shops to recharge money to buy the internet. Thus, they are deprived of media and cultural activities (Field interview, 2020). The central meaning units associated with the culture are:

"I was unable to participate in many national cultural programs held in the city. My area is far away from the urban cultural centres. [Student, Female].

I missed many games this year, like the national cricket and football match in the national stadium. The local buses 
stopped playing after 10 p.m. I must leave the stadium or miss the game for the lack of public transport. [Businessman, Female].

The student of the school or other educational institutions must travel on local buses. However, they are not given priority by the local bus drivers. Most of the students have to keep standing on the bus without a seat. [Student, Male]" (personal communication, February 2020).

Impact on Institutions, Legal and Political structures, and their Equity:

In Bangladesh, formal institutions, government, and nongovernment organisations and bodies tend to be found at the capital centre. People from Greater Dhaka who do not live at the centre have to spend more time, money and go through the struggle to enrol in these organisations and participate in decision making. They are aware that the choices and actions of centre-based independent agencies, private-sector corporations, educational institutions, and political organisations could directly affect their whole community politically and economically. In location no.3, no.5, and 6, the respondents reported that their ability to influence decisions is minimal. These local communities have to manage their social and economic changes on their own. This deprivation then led to the in-migration of communities into those centre areas and towns. It has caused a rise in housing and rental price for location no.3, no.5, and no. 6 of remote urban communities. Thus, people from locations no.3, 5, and 6 are founding them less in central institutional decision-making. As institutions, agencies, and the population have converted into more centralised. This condition is a clear example of marginalisation (Field interview, 2020). Some meaning units are:

"Dhaka city has the most intrinsic governmental and nongovernmental institutions. So, those who are far from this area have minimal chances of participating in national decisionmaking. [Government Employee, Male].

We have to rent a room or flat for our convenience in the capital as the travel cost is expensive. Besides, an apartment or room in the city's centre is also expensive for us. [Police, Male]" (personal communication, February 2020).

\section{Impact on Material Wellbeing:}

Material well-being is related to peoples' and communities' material standard of living, work and employment, income and spending, the worth of properties, debt and credit condition, economic reliance, and circulation of wealth and resources (Vanclay, 2002). The impacts of low or limited transport facilities on material well-being are discussed in the following paragraph.

The poor transport system is reducing employment or income opportunities in Dhaka. As most government job enrollment exams are held in the centre of the city in the morning of different holidays, many respondents from remote areas miss their schedule for traffic jams and public transport scarcity. It is tough to get a CNG auto-rickshaw (three-wheeler auto-rickshaw) or a typical vehicle during the rainy season. Because of that, those without dependable private or public transport tend to have high levels of joblessness or underemployment. This situation of deprivation contributes to low incomes as well as lowers the material quality of life. Sen (2000) described that unemployment causes social exclusion reducing the chances to interact with people in the community (p. 20). Through these interactions, people get to know about jobs and other economic prospects. The inadequate transport system disrupts these social interactions. The expenditure of individual households rises due to transport scarcity and varies from location by location. Due to poor access to transport, people rely more on local stores for food and supplies. These local stores are charac- teristically more costly than supermarkets or the central urban market. This additional expenditure negatively affects the communities in this study. In some cases, respondents limit the expenditure on other areas of life to compensate for costly local market expenditures. They cannot fulfil their fundamental needs, such as nutritional and health needs. There were no cases where the respondents did not talk about the traffic jam. The local buses block the way of the direct buses on every highway. Local buses have no specific stoppage. They operate on the road relentlessly for the money, violating traffic rules and disturbing the path of large direct buses in the city. Thus, local buses are causing traffic jams in this city. Traffic congestion in this city is responsible for wasting many working hours and vast amounts of money. There is no accountability for transport fares in all locations of study. From location no. 3, respondents reported that although the distance in road and river pass reduced due to the Dhaka Khulna expressway and the shifting of the "Kathalbari Ferry Ghat", the fare on this highway and waterways has not plumped. The transit owners tend to increase the fare when the distance increases; however, they do not reduce it when the distance declines. This incident is causing a massive loss of money from commuters every day (Field interview, 2020). The key meaning units are:

"We are losing jobs, and employment opportunities as all public examinations are usually held in Dhaka city. In the holidays all exams are held. It is challenging to take our exam on time. Again, in the holidays there is a lack of public transport. [Student, Male].

We cannot be able to carry the expenses of rent-a-car or CNG auto-rickshaw or taxi, mostly who are jobless. [Student, Male].

Transport scarcity causes a rise in expenditure as we have to rely on local shops. Local shops and markets and shops are more expensive for us than the central market. [Street Vendor or Hawker, Male].

When we spend more on transport, we must reduce the expenditure of others like our basic needs. [Businessman, Male].

An employee concluded that the transport authorities do not reduce the rent when the distance is reduced. However, they are always ready to increase the rent when the road distance is increased. [Doctor, Female].

All the local buses are competing for money and passengers. There is no accountability of exact fare for the transport authorities. [Police, Female]" (personal communication, February 2020).

Impact on Family, Community, and Social Networks:

The impacts of the inadequate transport system on social networks, communities, and families found in the studies are as follows:

The lack of transport accessibility reduces regular contact with relatives and family members for many respondents, causing family estrangement and enhancing social isolation in all study areas. People without a private car rely on the car-owning neighbour in a scary situation or an emergency. This incident strains their social relationships with their neighbour. In an emergency condition, they have to implore their car-owning neighbour for a car. The strain on such relationships later leads to social isolation. However, connecting with the broader society is indispensable for everyone. In modern society, people like face-to-face contact instead of the post, telephones, and computers to build and keep associations (Urry, 2007). Low or limited access to transport harshly limits the social capital available to people. In another case, many young respondents and the children cannot participate in their group weekend sports and entertainment for vehicle scarcity. This condition is disrupting 
their socialisation process. Thus, transport-related exclusion in Dhaka restrains people from group-based activities. This incident negatively affects social groups' solidity and causes a reduced sense of identity with the community. In urban communities, some members' segregation can lead to the expansion of new communities and groups, which reduce the wide-ranged community's harmony and viability. Later, it causes community severance in Dhaka. Community severance denotes the physical and psychological separation of neighbourhoods (Anciaes et al., 2016). However, looking for support and help for a car have positive effects too. It builds good relations among the neighbours in many locations (Field interview, 2020). Meaning units are:

"We cannot meet our relatives on many occasions for the high rent and lack of public transport. [Businessman, Female].

The relation with car-owning relatives and neighbours was weakened for the emergency medical issues. [Businessman, Male].

I have to live far away from my family, as inadequate transport facilities take away a great deal of time to be back home every day. [Professional driver, Male].

The low access to the car disrupts socialisation and the contract with broader society. [Engineer, Male]" (personal communication, February 2020).

\section{Impact on Fears and Aspiration:}

People having specific mental issues can fear travel (Wittchen et al., 2010). Anxiety over violence can prevent people from travelling. It can also affect transit ridership and revenue (Reed, Wallace, and Rodriguez, 2000; Wallace et al., 1999). Most of the bus stops in the study have no arrangement of proper safety for passengers and commuters. Buses are not a friendly place for women at all. Location no. 5 is the largest bus terminal (Gabtoli Bus Terminal) in the country. Extortion, hijacking, robbery is widespread in this bus station area. Tramps and vagrants are permanent residents in this terminal who earn their livelihood through those illegal means. They are uprooted people from different parts of our country and are making money in the guise of helpless people. They often resort to crime and deviant activities. Passengers and commuters are not safe when they arrive late at night at this station. The late-night travellers have to stay at this terminal until the sun comes up due to fear of potential hijacking. It is also relevant at location no.4. Those who use public transport in comparatively remote areas in locations no. 3 and 6 suffer heightened fear of attack while waiting for buses and leaving the station after arrival from somewhere else. Street lighting is absent in these remote areas. Another different case from our study is location no.3. On the weekends, people who arrive late from other parts of the country cannot catch the local buses inside Dhaka. This situation leaves them unsafe as there is no suitable rest house or waiting corner for the travellers. Female travellers in this situation suffer the most. They have to wait a long time, sometimes even half a day, for their safety (Field interview, 2020). The main meaning units are:

"In this area, extortion, hijack, robbery is executed by the trovers and urban ghettos. They are united and robust and stay permanently in this area. [Police, Male].

At this bus stop, we have no rest house. There are no facilities to stay at this station for the whole night if we are late. We are not safe from the unexpected attack as most of the road is absent in light. [Doctor, Female].

We must enter or leave Dhaka city every weekend. If we are late for any unavoidable circumstances, we must suffer much. We have no safety in this area after the evening on the road. [Government Employee, Female].

In this area, location no.4, we have to stay on launch after arriving for our safety. If we leave the launch, we would be in danger. After darkness goes, we get out from the launch. [Student, Female]" (personal communication, February 2020).

\subsection{CONCLUSION AND IMPLICATIONS:}

Spending a considerable amount of capitals and time is needed to develop the transport facilities, but it remains irretrievable in most circumstances (Alam and Habib, 2003). Likewise, this study finds that the bad traffic condition of the city of Dhaka has not improved over the years despite steps taken by the authority. The new strategies and the wideranging infrastructure overhaul have not come to fruition. New policies are coming every year, but the government and transport authority's prior and established interventions are not assessed. The difficulties intensify when transport problems affect the social settings of urban communities. Nevertheless, there is little research related to the social impact of poor transport conditions in this city. Most of the transport sector budget is spent on the construction of roads, bridges, and infrastructures. Investment in new transportation substructures has the ability to increase access to essential life-enhancing resources while also helping to encourage social integration and reduce inequality among economically vulnerable communities (Lucas, 2004; Lucas, Tyler, and Christodoulou, 2008). However, the various social matters such as transport poverty, social capital loss, equal transport accessibility, social exclusions, social seclusion, social isolation, loss of social networking, economic loss, and awareness-raising initiatives do not get importance. Therefore, Dhaka must invest more in the transit sector, giving equal priority to these transport-related social phenomena. It is not entirely impossible to eradicate Dhaka's traffic problems, but it will require much effort and hard work. The traffic speed has also decreased to near walking speed of $6.4 \mathrm{~km} /$ hour in this city (Gallagher, 2017). If the present condition continues, the situation will be out of our reach. So, we need a healthy, unified, and sustainable traffic system that prioritises integrated development policies, access to services, employment opportunities, pollution reduction, lessening traffic injuries, reducing community severance, and eliminating unhealthy transport in the transport sector. A sustainable urban transportation system can balance social, economic, and environmental priorities through equal decision-making from every sector. We have to train our drivers, pedestrians, and passengers of traffic rules and regulations appropriately because still, they do not know how to act across various transport situation. The separation of the lane, safe road crossing facilities, constructions of sidewalks, speed breaker, foot overbridge, higher meridians, abolishing fragmented transport authorities, raising the workforce in the transport sector, and subsidies in the public transports are now a vital need in this sector of the country. With this sector's development, a considerable number of jobs for people can be formed. Still, the city is fighting a losing battle against this city's development and fails to reduce the damaging and unhealthy social impacts of transportation. Therefore, the city authority must change Dhaka's existing transit system, giving equal priority to the social phenomena alongside technology and infrastructurebased development.

\section{Acknowledgement:}

The author is grateful to Tamim Ahmed, Research Assistant, Centre for Policy Dialogue, (CPD, Bangladesh), Afzal Ahmed, a student of the civil engineering department BUET (now Teacher of BSMRSTU at the civil engineering department) and Bipul, a student of Department of Economics, at North-South University Bangladesh (NSU) for their support. 


\section{Funding Sources:}

The author had no funding sources for this research. The author spent all the expenditures related to this research.

\section{Compliance and Ethical Interest:}

The author and who helped the author in this work have no conflict of interest. All the pieces of information and sources were directly collected from field interview and secondary resources. The author is solely responsible for the remaining faults.

\subsection{REFERENCES}

Abir, A. M., \& Hoque, M. S. (2011). A study on mobility problems of disabled people in Dhaka City. In Noor, Amin, Bhuiyan, Chowdhury, and Kakoli (Eds.), 4th Annual Paper Meet and 1st Civil Engineering Congress. Conference Proceedings of Civil Engineering Division, Institution of Engineers, Dhaka, Bangladesh. Retrieved from http://www.iebconferences.info/abir.pdf

Ahmed, S. S., \& Ahmed, M. (2017). Urbanisation and Economic Development of Bangladesh: The Primacy of Dhaka and Competitiveness. Retrieved from https://bea-bd.org/site/ images/pdf/new17/4.pdf

Ahmed, I., Alam, N. E., \& Warda, F. (2017). A Sustainable Urban Transport Initiative in Dhaka: Introducing Bus Rapid Transit System. Transport and Communication Bulletin for Asia and the Pacific. Retrieved from https://www.unescap.org/sites/default/ files/bulletin 87 5\%20A\%20Sustainable\%20Urban\%20Tra nsport\%20Initiative\%20in\%20Dhaka\%20- \%20Introducing\%20 Bus\%20Rapid\%20Transit\%20System.pdf

Alam, J. B., \& Habib, K. N. (2003). Effects of Alternative Transportation Options on Congestion and Air Pollution in Dhaka City. Journal of Civil Engineering, 31(2), 165-175. Retrieved from https://tspace. library.utoronto.ca/bitstream/1807/73938/1/2003_Effects\%20 of\%20Alt\%20Transp\%20Options\%20on\%20Congestion\%20and\%20 Air\%20Pollution.pdf

Anciaes, P. R., Boniface, S., Dhanani, A., Mindell, J. S., \& Groceb, N. (2016). Urban transport and community severance: Linking research and policy to link people and places. Journal of Transport \& Health, 3(3), 268-277. doi:10.1016/j.jth.2016.07.006

Andaleeb, S. S., Haq, M., \& Ahmed, R. I. (2007). Reforming inner city bus transportation in a developing country: A passengerdriven model. Journal of Public Transportation, 10(1), 1-25. doi:10.5038/2375-0901.10.1.1

Atkins, S. (1989). Critical Paths: Designing for Secure Travel. London: Design Council.

Barua, U., \& Tay, R. (2010). Severity of urban transit crashes in Bangladesh. Journal of Advanced Transportation, 43(1), 34-41. doi:10.1002/atr.104

BBS. (2019). Statistical Pocketbook of Bangladesh. Dhaka: Bangladesh Bureau of Statistics.

Bergstad, C. J., Gamble, A., Gärling, T., Hagman, O., Polk, M., Ettema, D., Friman, M., \& Olsson, L. E. (2011). Subjective wellbeing related to satisfaction with daily travel. Transportation, 38, 1-15. doi:10.1007/s11116-010-9283-z

Berg, B. L. (2001). Qualitative research methods for the social sciences. Boston: Allyn and Bacon.

Bengtsson, M. (2016). How to Plan and Perform a Qualitative Study Using Content Analysis. Nursing Plus Open, 2, 8-14. doi:10.1016/j.npls.2016.01.001

Bostock, L. (2001). Pathways of disadvantage? Walking as a mode of transport among low-income mothers. Health Soc Care Community, 9(1), 11-8. doi:10.1046/j.1365-2524.2001.00275.x.

Bosselmann, P., Macdonald, E., \& Kronemeyer, T. (1999). Livable Streets Revisited. Journal of the American Planning Association, 65(2), 168-180.doi:10.1080/01944369908976045

Church, A., Frost, M., \& Sullivan, K. (2000). Transport and social exclusion in London. Transport Policy, 7(3): 195-205. doi:10.1016/S0967-070X(00)00024-X
Coyne, I. T. (1997). Sampling in qualitative research.

Purposeful and theoretical sampling; merging or clear boundaries? Journal of advanced nursing, 26(3), 623-630. doi:10.1046/j.1365-2648.1997.t01-25-00999.x

Dunckel-Graglia, A. (2013) Women-only transportation: How 'pink' public transportation changes public perception of women's mobility. Journal of Public Transportation, 16(2): 85106. doi:10.5038/2375-0901.16.2.5

Ettema, D., Gärling, T., Eriksson, L., Friman, M., Olsson, L. E., \& Fujii, S. (2011). Satisfaction with travel and subjective well-being: development and test of a measurement tool. Transportation Research Part F: Traffic Psychology and Behaviour, 14(3), 167-175. doi:10.1016/j.trf.2010.11.002

Farrugia B. (2019). WASP (write a scientific paper): Sampling in qualitative research. Early human development, 133, 69-71. doi:10.1016/j.earlhumdev.2019.03.016

Fitzgerald, G. (2012). The social impacts of poor access to transport in rural New Zealand. NZ Transport Agency research report 484.

Foley, L., Prins, R., Crawford, F., Humphreys, D., Mitchell, R., Sahlqvist, S., Thomson, H., \& Friman, M., Gärling, T., Ettema, D., \& Olsson, L. E. (2017). How does travel affect emotional well-being and life satisfaction? Transportation Research Part A: Policy and Practice, 106, 170-180. doi:10.1016/j.tra.2017.09.024

Gallagher, R. (2017). Prioritising Dhaka's Urban Transport System. Journal of Business and Technology (Dhaka), 11(1), 141-144. doi:10.3329/jbt.v11i1.34247

Gardner, N., Cui, J., \& Coiacetto, E., (2017). Harassment on public transport and its impacts on women's travel behaviour. Australian Planner, 54(1), 8-15. doi:10.1080/07293682.2017.1299189

Gekoski, A. M., Jacqueline, M. H., Gray, S. E. Horvath, E., Aliye, \& J. Adler. (2015). What works' in reducing sexual harassment and sexual offences on public transport nationally and internationally: A rapid evidence assessment. Retrieved from https://eprints.mdx.ac.uk/15219/

Gekoski, A., Gray, J. M., Adler, J. R., \& Horvath, M., (2017). The prevalence and nature of sexual harassment and assault against women and girls on public transport: an international review. Journal of Criminological Research, Policy and Practice, 3(1), 3-16. doi:10.1108/JCRPP-08-2016-0016

Grady, M. P. (1998). Qualitative and Action Research: A Practitioner Handbook. Kappa Educational Foundation. Bloomington: Phi Delta Kappa.

Gray, D. E. (2014). Doing Research in the Real World (3 $3^{\text {rd }}$ ed). Thousand Oaks, California: Sage Publications.

Guest, G., Bunce, A., \& Johnson, L. (2006). How many interviews are enough? An experiment with data saturation and variability. Field Methods, 18(1), 59-82. doi:10.1177/1525822X05279903

Haq, M. A., Islam, M. M., Ali, M. S., Haque, M. F., \& Akhand, M. R. (2012). Status of Noise Pollution in Mixed Areas of Dhaka City: a GIS. Approach. Journal of Environmental Science and Natural Resources, 5(1), 9-17. doi: 10.3329/jesnr.v5i1.11548

Hsieh, H. F., \& Shannon, S. E. (2005). Three Approaches to Qualitative Content Analysis. Qualitative Health Research, 15(9), 1277-1288. doi:10.1177/1049732305276687

INTALInC. (2019). Transport and Social Exclusion in Bangladesh. Retrieved from https://intalinc.leeds.ac.uk/wp-content/ uploads/sites/28/2019/06/Bangaldesh-Scoping-Study.pdf

Jain, R., Urban, L., Balbach, H, \& Webb, M. D. (2012). Handbook of Environmental Engineering Assessment: Strategy, Planning, and Management. United Kingdom: Elsevier Butterworth-Heinemann

JICA \& DTCA. (2015). The Project on the Revision and Updating of the Strategic Transport Plan for Dhaka: Urban Transport Policy (draft). Dhaka: Almec Corporation, Oriental Consultants Global, Katahira \& Engineers International. Retrieved from https://dtca.portal.gov.bd/sites/default/files/files/dtca.portal. gov.bd/page/2c9ed98b_602a_468b_84bc_6b4858449313/DFR UrbanTransport\%20Policy\%20(Edited).pdf 
Kay, D. (2011). Fairness in a car-dependent society. London: Sustainable Development Commission.

Katz, D., \& Rahman, M. M. (2010). Levels of overcrowding in bus system of Dhaka, Bangladesh. Transportation Research Record: Journal of the Transportation Research Board, 2143(1), 85-91. doi:10.3141/2143-11

Khan, S. I., Khan, A., Sarker, N. I., Huda, N., Zaman, R. M.,.......\& Rahman, M. Z. (2018). Traffic Congestion in Dhaka city: Suffering for City Dwellers and Challenges for Sustainable Development. European Journal of Social Sciences, 57(1), 116-127. Retrieved from https://www. europeanjournalofsocialsciences.com/issues/PDF/ EJSS $57 \quad 1$ 09.pdf

Kondracki, N. L., Wellman, N. S., \& Amundson, D. R. (2002). Contentanalysis: Review of methods and their applications in nutrition education. Journal of Nutrition Education and Behavior, 34, 224-230. doi:10.1016/s1499-4046(06)60097-3

Krippendorff, K. (1980). Content Analysis: An Introduction to Its Methodology. Beverly Hills, CA: Sage.

Lockie, S. (2001) SIA in review: setting the agenda for impact assessment in the 21st century. Impact Assessment and Project Appraisal, 19(4), 277-287. doi:10.3152/147154601781766952

Loukaitou-Sideris, A. (2009). Addressing Women's Fear of Victimisation in Transportation Settings: A Survey of U.S. Transit Agencies. Urban Affairs Review, 44(4), 554-587. doi:10.1177/1078087408322874

Loukaitou-Sideris, A. (2014). Fear and safety in transit environments from the womens perspective. Security Journal, 27(2), 242-256. doi:10.1057/sj.2014.9

Loukaitou-Sideris, A. (2016). A gendered view of mobility and transport: next steps and future directions. Town Planning Review, 87(5), 547-565. doi:10.3828/tpr.2016.38

Lucas, K. (2004). Transport and social exclusion. Policy. In K. Lucas (Ed.), Running on empty: Transport, social exclusion and environmental justice (pp. 39-53). Bristol: Bristol University Press. doi: 10.2307/j.ctt1t89876.11

Lucas, K., Tyler, S., \& Christodoulou, G. (2008). The value of new transport in deprived areas. Joseph Rowntree Foundation.

Lucas, K. (2012). Transport and social exclusion: Where are we now? Transport Policy, 20(C), 105-113. doi:10.1016/j. tranpol.2012.01.013

Lyndon, H. \& Todd, T. (2006). Evaluating New Start Transit Program Performance: Comparing Rail and Bus. Canada: Victoria Transport Policy Institute.

Mackett, R. L. (2014). The health implications of inequalities in travel. Journal of Transport E Health, 1(3), 202-209. doi:10.1016/j.jth.2014.07.002

Mackett, R. L, \& Thoreau, R. (2015). Transport, social exclusion and health. Journal of Transport E Health, 2(4), 610-617. doi:10.1016/j.jth.2015.07.006

Mahmud, k., Gope, K., \& Chowdhury, S. R. (2012). Possible Causes $\&$ Solutions of Traffic Jam and Their Impact on the Economy of Dhaka City. Journal of Management and Sustainability, 2(2), 112-135. doi:10.5539/jms.v2n2p112

Mahmood, S. I. (2011). Air pollution kills 15,000 Bangladeshis each year: The role of public administration and government's integrity. Journal of Public Administration and Policy Research, 3(5), 129-140. doi:10.5897/JPAPR.9000004

Mannan, M. A., \& Ahmed, B. N. (2014). Baseline Survey of Safe City Program. Dhaka: Bangladesh Institute of Development Studies (BIDS).

McCarthy, S., \& Habib, M. A. (2018). Investigation of life satisfaction, travel, built environment and attitudes. Journal of Transport E Health, 11, 15-24. doi:10.1016/j. jth.2018.09.007

Mazumder, H., \& Pokharel, B. (2018): Sexual Violence on Public Transportation: A Threat to Women's Mobility in Bangladesh, Journal of Aggression, Maltreatment \& Trauma, 28(8), 1017-1019. doi:10.1080/10926771.2018.1491487
Metz, D. H. (2000). Mobility of older people and their quality of life, Transport Policy, 7(2),149-152, doi:10.1016/S0967070X(00)00004-4.

Miller, H. J. (2004). Travel Chances and Social Exclusion. Retrieved from https://www.researchgate.net/profile/Harvey_Miller/ publication/228602206_Travel_chances_and_social_exclusion/ links/00b495284d1285ca34000000.pdf

Mindell, J. S., Anciaes, P. R, Dhanani A, Stockton, J., Jones, P., Haklay, M., ......... \& Vaughan, L. (2017). Using triangulation to assess a suite of tools to measure community severance. Journal of Transport Geography, 60, 119-129. doi:10.1016/j. jtrangeo.2017.02.013

Mindell J. S., Cohen D. L., Shelton N. J, Sutaria, S., Hayward, A., $\&$ Watkins, S. J. (2014). Transport and clinical practice. Journal of Transport and Health, 1(1),73-80. doi:10.1016/j. jth.2013.08.001

Mitchell, C. B., \& Town, S. W. (1977). Accessibility of various social groups to different activities. Crowthorne: Transport and Road Research Laboratory. Supplementary Report, 258.

Momtaz, S. (2005). Institutionalising social impact assessment in Bangladesh resource management: limitations and opportunities. Environmental Impact Assessment Review, 25(1), 33-45. doi: 10.1016/j.eiar.2004.03.002

Moser, A., \& Korstjens, I. (2018) Series: Practical guidance to qualitative research. Part 3: Sampling, data collection and analysis. European Journal of General Practice, 24(1), 9-18, doi: 10.1080/13814788.2017.1375091

Mullan, E. (2003). Do you think that your local area is a good place for young people to grow up? The effects of traffic and car parking on young people's views. Health Place, 9(4), 351-360. doi:10.1016/S1353-8292(02)00069-2

Munsi, R. H. (2015). A STUDY ON NOISE HAZARD IN BUS INTERIOR IN DHAKA CITY (Unpublished Master's Thesis). Bangladesh University of Engineering and Technology, Dhaka, Bangladesh. Retrieved from http://lib.buet.ac.bd:8080/ xmlui/bitstream/handle/123456789/4649/Full\%20Thesis. pdf? sequence $=1$ \&isAllowed $=\mathrm{y}$

Mustaqeem, M. N., Jalaluddin, F., \& Hassan, R. (2016). Bus Network Coverage Analysis of Dhaka City Along with its Service Quality. Asian Journal of Innovative Research in Science, Engineering, and Technology (AJIRSET), 1(5), 1-8. Retrieved from http://www.engineeringjournal.info/index.php/AJIRSET/ article/view/19

Nasrin, S., Bunker, J., \& Zheng, Z. (2015). Worker Attitude toward Bus Rapid Transit: Considering Dhaka, Bangladesh. Transportation Research Record, 2533(1), 8-16. doi:10.3141/2533-02

Niger, M. (2013). Deficiencies of existing public transport system and a proposal for integrated hierarchical transport network as an improvement options: a case of Dhaka city. IOSR Journal of Mechanical and Civil Engineering, 5(5), 42-53. Retrieved from https://www.iosrjournals.org/iosr-jmce/papers/vol5-issue5/ F0554253.pdf?id=2461

Olsson, L. \& Thynell, M. (2006). Bangladesh Road Transport Corporation (BRTC) Bus Project in Dhaka. Department of Infrastructure and Economic Cooperation. Sweeden: Edita Communication.

Patton, M. Q. (2002). Qualitative research and evaluation methods ( $3^{\text {rd }}$ ed.). Thousand Oaks, CA: Sage.

Peters, D. (2013). Gender and sustainable urban mobility: Thematic study prepared for Global Report on Human Settlements 2013. Retrieved from http://civitas.eu/sites/default/files/unhabitat gender_surbanmobilitlity 0.pdf

Pierson, J. (2010). TACKLING SOCIAL EXCLUSION ( $2^{\text {nd }}$ ed.). London: Routledge

Quddus, M., Rahman, F., Monsuur, F., Ona, J. d., \& Enoch, M. (2019). Analysing Bus Passengers' Satisfaction in Dhaka using Discrete Choice Models. Transportation Research Record, 2673(2), 758-768. doi:10.1177/0361198119825846 
Rahman, M. S. (2010). Bus Service for Women Only in Dhaka City: An Investigation. Journal of Bangladesh Institute of Planners, 3, 17-32. Retrieved from http://www.bip.org.bd/SharingFiles/ journal book/20130722133425.pdf

Rahman, M., S., \& Nahrin, K. (2012). Bus Services in Dhaka City - Users' Experiences and Opinions. Journal of Bangladesh Institute of Planners, 5(1), 93-105. Retrieved from http://www.bip.org.bd/SharingFiles/journal book/20130820140314.pdf

Rahman, F., Das, T., Hadiuzzaman, M. \& Hossain, S. (2016). Perceived service quality of paratransit in developing countries: A structural equation approach. Transportation Research Part A: Policy and Practice, 93, 23-38. doi:10.1016/j. tra.2016.08.008

Reed, T. B., Wallace, R. R., \& Rodriguez, D. A. (2000). Transit Passenger Perceptions of Transit-Related Crime Reduction Measures. Transportation Research Record, 1731(1), 130-141. doi:10.3141/1731-16

Ross, C. E. (2000). Walking, exercising, and smoking: Does neighborhood matter? Social Science and Medicine, 51(2): 265-274. doi:10.1016/s0277-9536(99)00451-7

Rubin, A., \& Babbie, E. R. (2011). Research Methods for Social Work $\left(7^{\text {th }}\right.$ ed.). USA: Cengage Learning.

Schalkwyk, M. V., \& Mindell, J. S. (2018). Current issues in the impact of transport on health. British Medical Bulletin, 125(1), 67-77. doi:10.1093/bmb/ldx048

Sen, A. (2000). Social exclusion: concept application and scrutiny. Manila: Asian Development Bank.

Smith, G. D., \& Egger, M. (1992). Socioeconomic differences in mortality in Britain and the United States. American Journal of Public Health, 82(8), 1079-1081. doi:10.2105/ajph.82.8.1079

Smith, O. B. (2013). Peak of the Day or the Daily Grind: Commuting and Subjective Well-Being. (Dissertations and Theses). Portland State University. a Paper 1026. doi:10. 15760/ETD.1026

Stanley, J., J Stanley, Brodick, D. V., \& Currie, G. (2010). The place of transport in facilitating social inclusion via the mediating influence of social capital. Research in Transportation Economics, 29(1). 280-286. doi:10.1016/j.retrec.2010.07.035

Suter, W. N. (2012). Introduction to Educational Research: A Critical Thinking Approach ( $2^{\text {nd }}$ ed.). London: Sage.

United Nations, Department of Economic and Social Affairs, Population Division (2019). World Urbanization Prospects: The Revision (ST/ESA/SER.A/420). New York: United Nations. Retrieved from https://population.un.org/wup/Publications/ Files/WUP2018-Report.pdf

Urquhart, C. (2013). Grounded Theory for Qualitative Research: A Practical Guide. Thousand Oaks: SAGE.

Urry, J. (2007). Mobilities. Cambridge: Polity Press.

Vanclay, F. (2003). SIA principles: International Principles For Social Impact Assessment. Impact Assessment and Project Appraisal, 21(1), 5-11. doi:10.3152/147154603781766491

Vanclay, F. (2002) Conceptualising social impacts. Environment Impact Assessment Review, 22(3), 183-211. doi:10.1016/S01959255(01)00105-6.

Van Schooten, M., Vanclay, F., \& Slootweg, R. (2003) Conceptualising social change processes and social impacts. In H. A. Becker and F. M. Vanclay (Eds.), The international handbook of social impact assessment: conceptual and methodological advances. Cheltenham: Edward Elgar.

Wallace, R. R., Rodriguez, D. A., White, C., \& Levine, J. (1999). Who Noticed, Who Cares? Passenger Reactions to Transit Safety Measures. Transportation Research Record, 1666(1), 133-138. doi:10.3141/1666-16

Wittchen, H. U., Gloster, A. T., Baum, K. B, Fava, G. A., $\&$ Craske, M. G. (2010). Agoraphobia: a review of the diagnostic classificatory position and criteria. Depression and Anxiety, 27(2), 113-133. doi:10.1002/da.20646

Zahir, U. M., Matusi, H., \& Fujita, M. (2000). Investigate the effects of bus and passenger arrival patterns and service frequency on passenger waiting time and transit performance of Dhaka metropolitan area. Advances in Transport, 49(2000), 55-64. doi:10.2495/UT000051

\section{QUESTIONNAIRE OF THE INTERVIEW}

\section{Hello there!}

I am researching the Social Impact of inadequate transportation facilities in Dhaka city. I require conducting interviews with you to know your concern about transportation problems in your area. This research is exclusively for academic reasons, and I will keep all your responses a secret. I shall try to share the results of the study with you if I can complete it. I shall be very grateful if you agree to cooperate with me and give some of your valuable time for this interview. Thank you for your time.

(The original questionnaire was in the Bengali Language).

\begin{tabular}{|c|c|c|c|c|c|c|}
\hline $\begin{array}{l}\text { Name: } \\
\text { Location: } \\
\text { Ideograph }\end{array}$ & $\square$ L1 & $\square \mathbf{L} 2$ & $\square \mathbf{L 3}$ & $\square \mathbf{L 4}$ & $\square$ L5 & $\square$ L6 \\
\hline & & & & Earnings & & \\
\hline ................... & .......... & .......... & ....... & ……....... & ........... & ........... \\
\hline
\end{tabular}

1. What are the problems you face at the time of a health emergency with public transport in your area?

2. What kind of transport you have to use every day for travel?

3. Does your area have a local doctor, and are they capable of facing the challenges in health problems?

4. Do you think the inadequate transport facilities are degrading your job chances and opportunities? If yes, How?

5. Can you participate in cultural activities? Are cultural and political institutions far away from your home?

6. Do you face cultural deprivation due to adequate transport facilities?

7. Have you ever called for a car in an emergency from your neighbour?

8. What are the problems you face while visiting your relatives' house during a religious ceremony on the road?

9. Are the bus stop and the station safe in your area? If unsafe, what are the causes?

10. Does the bus station or bus stop have toilet facilities in this area? Describe, please.

11. Are non-registered vehicles creating problems for registered vehicles in your area?

12. Do you face different problems on the street and in public transport being women? What are the causes behind it you think or encounter?

13. Is the distance of mainstream political institution liable for the reduced political participation?

14. Have you ever faced any problem travelling to your relatives during a ceremony or celebration? 
15. How social capital and social networking are breaking down for the lack of transport?

16. Do you depend on the local market for your daily need? Which one is cheaper? Local or

17. Do the places of the vehicle stop and station occupy by anyone? What are the causes behind this?

18. What are the conditions of traffic in your area? Is traffic jam relevant in your area? Please describe.

19. Have you ever encountered a hijack or robbery on the bus or transport station? What was the leading cause you think for these?

20. What activities by the vehicle cause sound pollution, you think?

21. Have you ever injured or suffer from a travel accident? Describe Please.

22. Are you depriving of the mainstream participation of political institutions or practices? What are the reasons behind them?

23. Do you think if you have a private car, your everyday life would be more resilient? Explain?

24. How are you economically suffering from inadequate transport systems? Describe?

25. Can you and your children, family be able to participate in weekend sport, meetings, entertainment, or outing in this transport system? Elaborate, please. Are they out from the proper socialisation process?

26. Do you live far away from your family? What are the travel-related obstacles you face to meet with your family?

27. Describe the condition of the footpath and pavement of your area.

.....................

28. Describe the attitude of drivers and contractor in the transport in your area?

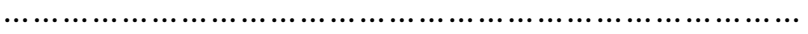

Table 3. Codes for Qualitative Content Analysis (QCA)

\begin{tabular}{l}
\hline Coding List for Qualitative Analysis \\
\hline Improper Management at Vehicle Stop \\
\hline Lack of safeness \\
\hline Violation of Social Seclusion \\
\hline Family Estrangement \\
\hline Social Isolation \\
\hline Reduced Social Networking \\
\hline Loss of Social Capital \\
\hline Disrupting Socialisation Process \\
\hline Isolated Self Identification in the Community, Community severance \\
\hline Economic Losses \\
\hline Joblessness, reducing Job Opportunities \\
\hline Disruption in Basic Human Needs
\end{tabular}

\begin{tabular}{l}
\hline Loss of Big Working Hours \\
\hline Traffic Rules Violations \\
\hline Rare Accountability towards Passengers by Transport Authority \\
\hline Cultural Deprivation \\
\hline Social Exclusion \\
\hline Marginalisation \\
\hline Mental Health Problem \\
\hline Environmental Pollution \\
\hline Deprived Medical Facilities \\
\hline Road Accident related injury \\
\hline Sound pollution \\
\hline Disrupting Traffic Flow \\
\hline Traffic Jam \\
\hline Loss of Social Interaction \\
\hline In-migration \\
\hline Bad Attitude by Drivers/Transport Authorities \\
\hline The extra fare in travel \\
\hline Note. List of codes collected from the case interview
\end{tabular}

